University of South Carolina

Scholar Commons

1975

\title{
Electrochemical Reduction of Molybdate in the Presence of Zinc Chloride in Molten Lithium Chloride-Potassium Chloride Eutectic
}

\author{
R. Cvetkovic \\ University Kiril and Metodij, Skopje, Yugoslavia \\ Branko N. Popov \\ University of South Carolina - Columbia, popov@engr.sc.edu \\ H. A. Laitinen \\ University of Florida
}

Follow this and additional works at: https://scholarcommons.sc.edu/eche_facpub

Part of the Chemical Engineering Commons

\author{
Publication Info \\ Journal of the Electrochemical Society, 1975, pages 1616-1619. \\ (C) The Electrochemical Society, Inc. 1975. All rights reserved. Except as provided under U.S. copyright law, \\ this work may not be reproduced, resold, distributed, or modified without the express permission of The \\ Electrochemical Society (ECS). The archival version of this work was published in the Journal of the \\ Electrochemical Society. \\ http://www.electrochem.org/ \\ DOI: $10.1149 / 1.2134079$ \\ http://dx.doi.org/10.1149/1.2134079
}

This Article is brought to you by the Chemical Engineering, Department of at Scholar Commons. It has been accepted for inclusion in Faculty Publications by an authorized administrator of Scholar Commons. For more information, please contact digres@mailbox.sc.edu. 


\title{
Electrochemical Reduction of Molybdate in the Presence of Zinc Chloride in Molten Lithium Chloride-Potassium Chloride Eutectic
}

\author{
R. Cretković and B. N. Popor \\ Faculty of Technology and Metallurgy, University Kiril and Metodij, Skopje 91000, Yugoslavia \\ and H. A. Laitinen* \\ Department of Chemistry, University of Florida, Gainesville, Florida 32611
}

\begin{abstract}
Two chronopotentiometric waves were observed for the electrochemical reduction of molybdate in the presence of zinc chloride, with quarter-wave potentials of $-1.5 \mathrm{~V}$ and $-1.75 \mathrm{~V} v \mathrm{~s}$. the $\mathrm{Pt}(\mathrm{II}) / \mathrm{Pt}$ reference electrode, respectively. It was observed that an increase in the molybdate concentration causes a decrease of the first transition time indicating a chemical reaction between $\mathrm{ZnCl}_{2}$ (which is reduced at $-1.5 \mathrm{~V}$ ) and $\mathrm{Li}_{2} \mathrm{MoO}_{4}$ in the melt forming $\mathrm{ZnMoO}_{4}$ which is sparingly dissociated in $\mathrm{LiCl}-\mathrm{KCl}$ eutectic. The equilibrium constant for the observed reaction was calculated. $\mathrm{X}$-ray powder diffraction patterns of the reduction product of $\mathrm{ZnMoO}_{4}$ have been obtained.
\end{abstract}

\begin{abstract}
Laitinen and Propp (1) have shown that the electrochemical reduction product of $\mathrm{K}_{2} \mathrm{CrO}_{4}$ in $\mathrm{LiCl}-\mathrm{KCl}$ eutectic containing dissolved $\mathrm{MgCl}_{2}$ is a single compound of formula $\mathrm{Li}_{x} \mathrm{Mg}_{y} \mathrm{CrO}_{4}$, where $x+2 y=5$. Laitinen and Hanck (2) observed that the reduction of chromate in the presence of $\mathrm{Zn}$ (II) was shifted from $-1.0 \mathrm{~V}$ vs. $\mathrm{Pt}(\mathrm{II}) / \mathrm{Pt}$ reference to $-0.5 \mathrm{~V}$. Analysis of the deposit indicated the composition to be $\mathrm{LiZn}_{2} \mathrm{CrO}_{4}$. Laitinen and Popov (3) also observed that when chromate is reduced in the presence of $\mathrm{NiCl}_{2}$ at $500^{\circ} \mathrm{C}$ the deposit approaches the composition $\mathrm{LiNi}_{2} \mathrm{CrO}_{4}$.

The purpose of the present research is to characterize the insoluble electrode deposit formed when $\mathrm{Li}_{2} \mathrm{MoO}_{4}$ is reduced in the presence of $\mathrm{ZnCl}_{2}$ in $\mathrm{LiCl}-$ $\mathrm{KCl}$ eutectic. The knowledge gained through this study will contribute to the over-all understanding of molybdate electrochemistry $(4,5)$ and should aid the interpretation of the mechanism of the electrochemical reduction of $\mathrm{Li}_{2} \mathrm{MoO}_{4}$ in $\mathrm{LiCl}-\mathrm{KCl}$ eutectic.
\end{abstract}

\section{Experimental}

Solvent.-The eutectic mixture of potassium chloride [41 mole per cent $(\mathrm{m} / \mathrm{o})$ ] and lithium chloride (59 $\mathrm{m} / \mathrm{o}$ ) at $450^{\circ} \mathrm{C}$ was used as a solvent system. The $\mathrm{LiCl}-\mathrm{KCl}$ eutectic was obtained from Anderson Physics Laboratories, Incorporated, Champaign, Illinois. The method of purification has been described (1).

Apparatus.-The instrumentation and equipment used in this study have been previously described (1-5).

Electrolytic cell.-.The cell used in this experiment has been previously described (6). Within this cell and under an atmosphere of dry, oxygen-free argon, the solvent was allowed to collect into the fritted compartments which were used as experimental cells. At the end of the experiment the volume of each compartment was determined by titrating its chloride content, and making calculations from the known density of the melt at $450^{\circ} \mathrm{C}$.

Electrodes.-The reference electrode was a platinum foil in contact with platinum(II) solution. This reference electrode has been shown to be reproducible and nonpolarizable over a long period of time (7). The Pt indicator electrode used in this study has been pre-

* Electrochemical Society Active Member.

Key wards: fused salts, zine molybdate, chronopotentiometry. viously described (1-5). The electrode had a geometric area of $0.5 \mathrm{~cm}^{2}$ and was constructed so that the glassmetal seal was always kept above the level of the melt. The platinum gauze electrodes used to prepare samples of the film, as well as the carbon electrode which served as counterelectrode in all electrochemical investigations in the melt, were constructed as described by Propp (1).

Chemicals.-All chemicals used in this study were reagent grade. $\mathrm{ZnMoO}_{4}$ was prepared by fusion of $\mathrm{ZnO}$ and $\mathrm{MoO}_{3}$ at $700^{\circ} \mathrm{C}(8)$ as well as by the methods described by Schultze (9), Carriere (10), and Jander (11). The product was light rose in color and has been identified by $x$-ray and chemical analysis as $\mathrm{ZnMoO}_{4}$. Those chemicals containing water of hydration were vacuum dried at $110^{\circ} \mathrm{C}$ before being added to the melt. Solid chemicals were added to the melt by means of a small glass spoon. A blanket of argon was kept over the melt at all times to exclude oxygen and water vapor. The purification train used in purifying the argon has been described (1-5).

Experimental techniques.-Samples of the electrode deposit resulting from the reduction were obtained by constant current electrolysis using platinum gauze electrodes. Before their insertion in the melt solution, the gauze electrodes were cleaned in boiling, concentrated $\mathrm{HNO}_{3}$, rinsed with distilled water, and dried at $130^{\circ} \mathrm{C}$ for $20 \mathrm{hr}$. After the material had been deposited on the electrode, the electrode was allowed to cool, washed with deionized water, and dried at $120^{\circ} \mathrm{C}$. The deposits were then dissolved in $5 \mathrm{ml}$ of concentrated nitric acid by heating on a hot plate. The zinc content of the solution was conveniently determined by a simple EDTA titration with Eriochrome Black $T$ as the indicator. The molybdenum content of the deposit was determined by addition of an excess of $\mathrm{Pb}^{2}+$ which was backtitrated with EDTA using xylenol orange as the indicator. The total molybdenum was also obtained by amperometric titration with lead, a procedure developed by Aylward (12). The lithium content was determined using flame photometry, observing the $\mathrm{Li}$ emission at $670.8 \mathrm{~nm}$. X-ray powder diffraction patterns were obtained using an $11.47 \sim \mathrm{cm}$ camera loaded with Ilford Type $\mathrm{G}$ x-ray film and exposed to $\mathrm{Ni}$ filtered $\mathrm{CuK} \alpha$ radiation. The $\mathrm{Cu}$ tube was mounted in a Norelco generator. Chloride was determined by the Volhard method. 


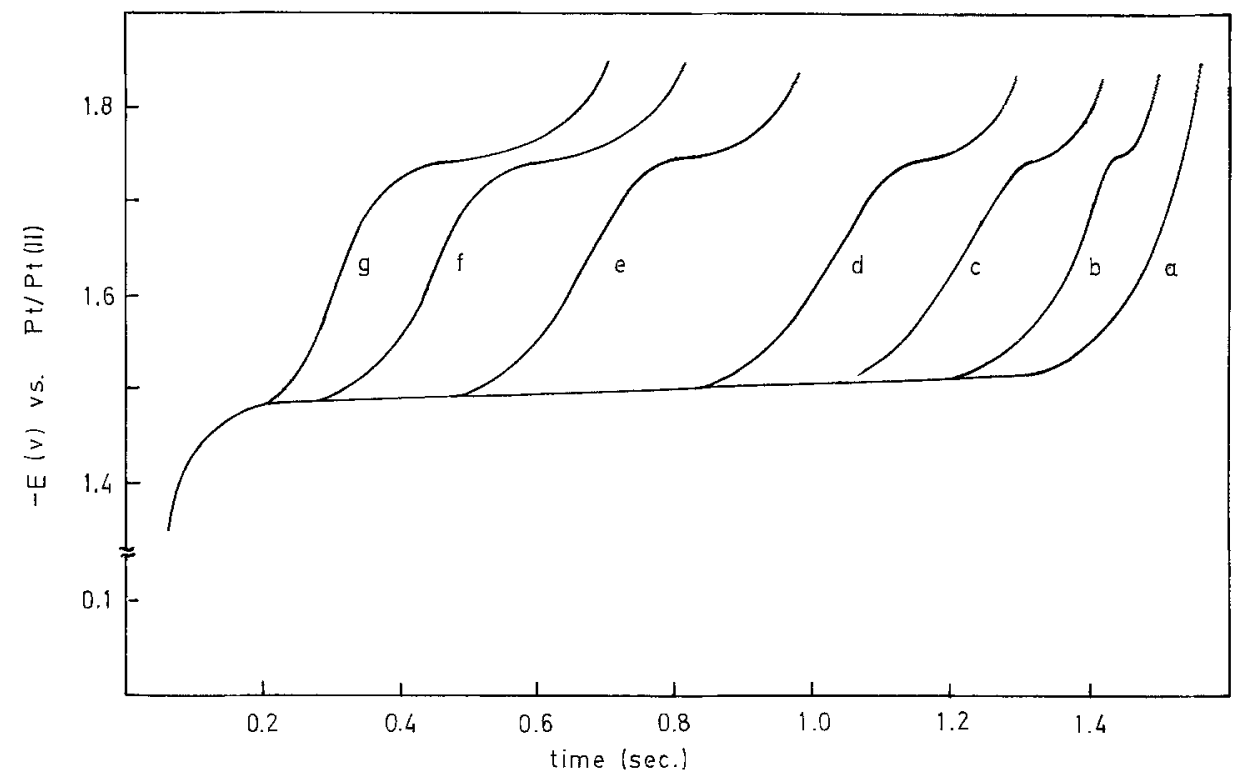

Fig. 1. Potential-time curves for chronopotentiometric reduction of mixture $\mathrm{ZnCl}_{2}-\mathrm{Li}_{2} \mathrm{MoO}_{4}$. Current density $=50.4 \mathrm{mM} /$ $\mathrm{cm}^{2}$.

$\begin{array}{cc}\text { Concen- } & \text { Concen- } \\ \text { tration of } & \text { tration of } \\ \mathrm{ZnCl}_{2}, \mathrm{~mm} \mathrm{Li}_{2} \mathrm{MoO}_{4}, \mathrm{~mm}\end{array}$

\section{Results and Discussion}

$\mathrm{ZnCl}_{2}-\mathrm{Li}_{2} \mathrm{MoO}_{4}-\mathrm{LiCl}-\mathrm{KCl}$ system.-Under certain conditions one chronopotentiometric wave is observed for the reduction of $\mathrm{Li}_{2} \mathrm{MoO}_{4}$ at $-1.75 \mathrm{~V} v s$, the $\mathrm{Pt}(\mathrm{II}) /$ Pt reference electrode. This reduction was found to be diffusion controlled over the time interval investigated. Chronopotentiograms were obtained over the concentration range $\left(5.3 \times 10^{-3} \mathrm{M} \mathrm{Li}_{2} \mathrm{MoO}_{4}-153.3 \times\right.$ $\left.10^{-3} M\right)$. The average value of $I \tau^{1 / 2} / C$ calculated from the chronopotentiometric results is $175 \mathrm{~A} \mathrm{sec}^{1 / 2} \mathrm{~mole}^{-1}$ $\mathrm{cm}^{3}$, which agrees with the results obtained earlier $(4,5)$.

Chronopotentiometry of $\mathrm{ZnCl}_{2}$ in the absence of $\mathrm{Li}_{2} \mathrm{MoO}_{4}$ revealed a wave with a quarter-wave potential of $-1.5 \mathrm{~V} v s$, the $\mathrm{Pt}$ (II)/Pt reference electrode. Diffusion control was shown by the constancy of $I \tau^{1 / 2} / C$ at $800 \pm 4 \mathrm{~A} \mathrm{sec}^{1 / 2} \mathrm{~mole}^{-1} \mathrm{~cm}$ for four different concentrations ranging from $8.34 \times 10^{-3} M$ to $125 \times 10^{-3} M$ at three different current densities. The above value of $I \tau^{1 / 2} / \mathrm{C}$ was used as a calibration factor for evaluating $\mathrm{Zn}$ (II) concentration in calculating the formation constant of $\mathrm{ZnMoO}_{4}$.

The effect of $\mathrm{Zn}$ (II) on the reduction of $\mathrm{Li}_{2} \mathrm{MoO}_{4}$ was demonstrated by successively increasing the concentration of $\mathrm{Li}_{2} \mathrm{MoO}_{4}$ at constant $\mathrm{Zn}$ (II) concentration as shown in Fig. 1. Two chronopotentiometric waves were observed. The first wave has a quarter-wave potential at $-1.5 \mathrm{~V}$ vs. the $\mathrm{Pt}$ (II) $/ \mathrm{Pt}$ reference electrode corresponding to the reduction of $\mathrm{Zn}$ (II) and the other at $-1.75 \mathrm{~V}$ corresponding to the reduction of molybdate. It was observed that an increase on the molybdate concentration in the melt causes a decrease of the first transition time and at the same time an increase of the second transition time. The quantitative variation of the transition time constant was tested by running duplicates of three current densities at different $\mathrm{Li}_{2} \mathrm{MoO}_{4}$ concentrations. The decrease of $I_{0} \tau^{1 / 2}$, for the reduction step at $-1.5 \mathrm{~V}$, with increasing $\mathrm{Li}_{2} \mathrm{MoO}_{4}$ concentration, is demonstrated in Table I.

The chronopotentiometric data for the second reduction are presented in Table II.

The data in Tables I and II can be quantitatively interpreted in terms of an equilibrium

$$
K=\frac{\left[\mathrm{Zn} \mathrm{MoO}_{4}\right]}{\left[\mathrm{Zn}^{2+}\right]\left[\mathrm{MoO}_{4}{ }^{2-}\right]}=\frac{X}{\left(\mathrm{C}_{\mathrm{ZnCl}_{2}}-X\right)\left(\mathrm{CoO}_{\mathrm{Li}_{2} \mathrm{MoO}_{4}}-X\right)}
$$

The results, given in Table III indicate that $K=30.1$ \pm 2.9 , as calculated from the data in Table $I$.

$\mathrm{ZnMoO}_{4}-\mathrm{LiCl}-\mathrm{KCl}$ system.-In order to examine further the electrochemical reduction of $\mathrm{Li}_{2} \mathrm{MoO}_{4}$ in the presence of $\mathrm{ZnCl}_{2}$, chronopotentiograms of $\mathrm{ZnMoO}_{4}$ in molten LiCl-KCl were obtained.

Qualitatively, two chronopotentiometric waves occur in the case of $\mathrm{ZnMoO}$ reduction with quarter-wave potentials at $-1.5 \mathrm{~V}$ and at $-1.75 \mathrm{~V}$ vs. the $\mathrm{Pt}$ (II) $/ \mathrm{Pt}$ reference electrode.

The Sand equation was tested by running duplicates of four current densities at five different $\mathrm{ZnMoO}_{4}$ concentrations. The dependence of $I_{0} \tau^{1 / 2}$ on $C$ is demonstrated in Table IV for the first wave and in Table $V$ for the second reduction.

The data in Tables IV and $\mathrm{V}$ can be quantitatively interpreted in terms of an equilibrium

$$
\mathrm{ZnMoO}_{4} \rightleftarrows \mathrm{Zn}^{2+}+\mathrm{MoO}_{4}^{2-}
$$

In order to compare the results given in Table IV for the system $\mathrm{ZnMoO}_{4}$ with those obtained for the system $\mathrm{Li}_{2} \mathrm{MoO}_{4}-\mathrm{ZnCl}_{2}$ one can write for the above equilibrium

$$
K=\frac{\left[\mathrm{ZnMoO}_{4}\right]}{\left[\mathrm{Zn}^{2+}\right]\left[\mathrm{MoO}_{4}^{2-}\right]}=\frac{\left(\mathrm{CZnMoO}_{4}-X\right)}{X^{2}}
$$

\begin{tabular}{|c|c|c|c|c|}
\hline $\begin{array}{l}\mathrm{CLi}_{2} \mathrm{MoO}_{4} \\
(\mathrm{M})\end{array}$ & $\mathrm{mA} \cdot I_{0}$ & $\tau$, sec & & $\begin{array}{l}I_{0} \tau^{1 / 2} \\
\left(\mathrm{~A} \cdot \mathrm{sec}^{1 / 2}\right. \\
\left.\mathrm{cm}^{-2}\right)\end{array}$ \\
\hline \multirow[t]{2}{*}{$7.55 \cdot 10^{-3}$} & $\begin{array}{l}50.4 \\
57.8 \\
69.8\end{array}$ & $\begin{array}{l}1.20 \\
0.90 \\
0.65\end{array}$ & & $\begin{array}{l}55.2 \cdot 10^{-3} \\
54.9 \cdot 10^{-3} \\
56.3 \cdot 10^{-3}\end{array}$ \\
\hline & & & Avg & $55.4 \cdot 10^{-3}$ \\
\hline \multirow[t]{2}{*}{$19.30 \cdot 10^{-3}$} & $\begin{array}{l}50.4 \\
57.8 \\
69.8\end{array}$ & $\begin{array}{l}1.00 \\
0.70 \\
0.55\end{array}$ & & $\begin{array}{l}50.4 \cdot 10^{-3} \\
48.4 \\
51.7 \cdot 10^{-3}\end{array}$ \\
\hline & & & Avg & $50.2 \cdot 10^{-3}$ \\
\hline \multirow[t]{2}{*}{$32.7 \cdot 10^{-3}$} & $\begin{array}{l}50.4 \\
57.8 \\
69.8\end{array}$ & $\begin{array}{l}0.75 \\
0.55 \\
0.40\end{array}$ & & $\begin{array}{l}43.6 \cdot 10^{-3} \\
42.8 \cdot 10^{-3} \\
44.1 \cdot 10^{-3}\end{array}$ \\
\hline & & & Avg & $43.5 \cdot 10^{-3}$ \\
\hline \multirow[t]{2}{*}{$51.8 \cdot 10^{-3}$} & $\begin{array}{l}50.4 \\
57.8 \\
69.8\end{array}$ & $\begin{array}{l}0.45 \\
0.40 \\
0.25\end{array}$ & & $\begin{array}{l}33.8 \cdot 10^{-3} \\
36.6 \\
34.9 \cdot 10^{-3}\end{array}$ \\
\hline & & & Avg & $35.1 \cdot 10^{-3}$ \\
\hline \multirow[t]{2}{*}{$87.8 \cdot 10^{-3}$} & $\begin{array}{l}40.4 \\
50.4 \\
57.8\end{array}$ & $\begin{array}{l}0.40 \\
0.25 \\
0.15\end{array}$ & & $\begin{array}{l}25.6 \cdot 10^{-3} \\
25.2 \cdot 10^{-3} \\
22.4 \cdot 10^{-9}\end{array}$ \\
\hline & & & Avg & $24.4 \cdot 10^{-3}$ \\
\hline \multirow[t]{2}{*}{$118.5 \cdot 10^{-3}$} & $\begin{array}{l}36.2 \\
40.4 \\
50.4\end{array}$ & $\begin{array}{l}0.25 \\
0.20 \\
0.15\end{array}$ & & $\begin{array}{l}18.1 \cdot 10^{-3} \\
18.1 \cdot 10^{-3} \\
19.5 \cdot 10^{-3}\end{array}$ \\
\hline & & & Avg & $18.6 \cdot 10^{-s}$ \\
\hline
\end{tabular}

Table I. Chronopotentiometric data for the first reduction step of $\mathrm{ZnCl}_{2}$ and $\mathrm{Li}_{2} \mathrm{MoO}_{4}$ mixtures

$$
\mathrm{CZnCl}_{2}=74 \cdot 10^{-3}(\mathrm{M})
$$


Table II. Chronopotentiometric data for the second reduction step of $\mathrm{ZnCl}_{2}$ and $\mathrm{Li}_{2} \mathrm{MoO}_{4}$ mixtures

$\mathrm{C}_{\mathrm{ZnCl}_{2}}=74 \cdot 10^{-3}(\mathrm{M})$

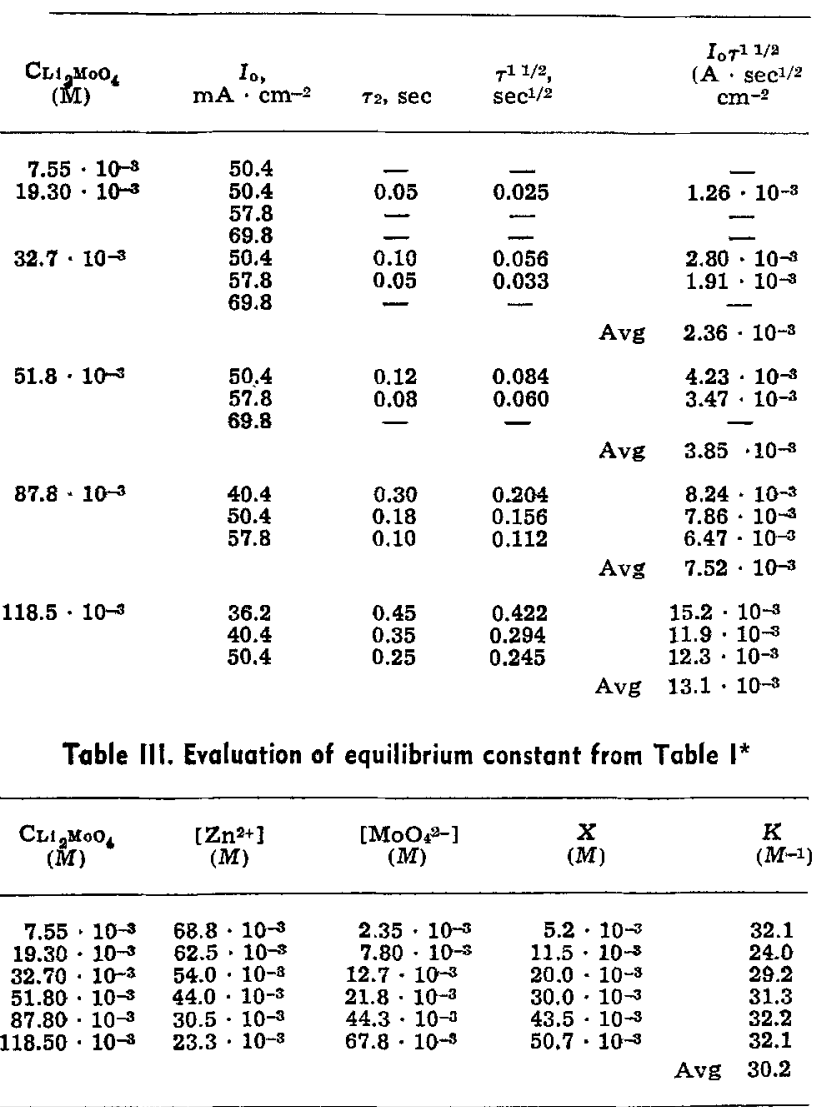

- Standard deviation is $\mathbf{\pm 2 . 9 4}$.

Table IV. Chronopotentiometric dota for the first reduction step of $\mathrm{ZnMoO}_{4}$

\begin{tabular}{|c|c|c|c|c|}
\hline$\underset{(\mathrm{M})}{\mathrm{CznMoO}_{4}}$ & $\mathrm{~mA}^{I_{0},} \mathrm{~cm}^{-2}$ & $\tau, \sec$ & & $\begin{array}{c}I_{0} \tau^{1 / 2} \\
\left(\mathrm{~A} \cdot \sec ^{1 / 2}\right. \\
\left.\mathrm{cm}^{-2}\right)\end{array}$ \\
\hline \multirow[t]{2}{*}{$29.05 \cdot 10^{-3}$} & $\begin{array}{l}14.4 \\
20.0 \\
24.4 \\
30.2\end{array}$ & $\begin{array}{l}1.05 \\
0.50 \\
0.38 \\
0.24\end{array}$ & & $\begin{array}{l}14.8 \cdot 10^{-\mathrm{s}} \\
14.1: 10^{-\mathrm{s}} \\
15.1: 10^{-3} \\
14.8 \cdot 10^{-3}\end{array}$ \\
\hline & & & Avg & $14.7 \cdot 10^{-3}$ \\
\hline \multirow[t]{2}{*}{$44.3 \cdot 10^{-3}$} & $\begin{array}{l}14.4 \\
20.0 \\
30.2 \\
36.2\end{array}$ & $\begin{array}{l}1.80 \\
0.95 \\
0.46 \\
0.32\end{array}$ & & $\begin{array}{l}19.3 \cdot 10^{-3} \\
19.5 \cdot 10^{-3} \\
20.4 \cdot 10^{-3} \\
20.4 \cdot 10^{-3}\end{array}$ \\
\hline & & & Avg & $20.0 \cdot 10^{-3}$ \\
\hline \multirow[t]{2}{*}{$87.9 \cdot 10^{-9}$} & $\begin{array}{l}30.2 \\
36.2 \\
40.4 \\
50.4\end{array}$ & $\begin{array}{l}1.00 \\
0.78 \\
0.60 \\
0.40\end{array}$ & & $\begin{array}{l}30.2 \cdot 10^{-3} \\
32.0 \cdot 10^{-3} \\
31.3 \cdot 10^{-3} \\
32.0 \cdot 10^{-8}\end{array}$ \\
\hline & & & Avg & $31.4 \cdot 10^{-3}$ \\
\hline \multirow[t]{2}{*}{$107.0 \cdot 10$} & $\begin{array}{l}30.2 \\
36.2 \\
40.4 \\
50.4\end{array}$ & $\begin{array}{l}1.45 \\
0.94 \\
0.74 \\
0.50\end{array}$ & & $\begin{array}{l}36.4 \cdot 10^{-8} \\
35.3 \cdot 10^{-3} \\
34.7 \cdot 10^{-8} \\
35.7 \cdot 10^{-8}\end{array}$ \\
\hline & & & Avg & $35.5 \cdot 10^{-3}$ \\
\hline \multirow[t]{2}{*}{$142.7 \cdot 10^{-3}$} & $\begin{array}{l}30.2 \\
36.2 \\
40.4 \\
50.4\end{array}$ & $\begin{array}{l}1.90 \\
1.42 \\
1.10 \\
0.70\end{array}$ & & $\begin{array}{l}41.7 \cdot 10^{-3} \\
43.2 \cdot 10^{-3} \\
42.4 \cdot 10^{-3} \\
42.2 \cdot 10^{-3}\end{array}$ \\
\hline & & & Avg & $42.4 \cdot 10^{-3}$ \\
\hline
\end{tabular}

The results given in Table VI for the equilibrium constant have been obtained using the data from Table IV.

Characterization of electrode deposit.-Samples of electrode deposit were prepared by constant current electrolysis. The cathode was immersed into $3.7 \mathrm{ml}$ $0.035 \mathrm{M} \mathrm{ZnMoO}_{4}$ and attempts were made to prepare coulometrically the reduction product at $-1.5 \mathrm{~V}$. It was
Table V. Chronopotentiometric data for the second reduction step of $\mathrm{ZnMOO}_{4}$

\begin{tabular}{|c|c|c|c|c|c|}
\hline $\begin{array}{c}\mathrm{CZnMaO}_{4} \\
\text { (IM) }\end{array}$ & $\mathrm{mA}^{I_{\mathbf{o}_{1}}} \cdot 10^{-2}$ & $\tau 2, \mathrm{sec}$ & $\begin{array}{l}\tau^{1} 1 / 2 \\
\sec ^{1 / 2}\end{array}$ & & $\begin{array}{c}I_{0} \mathrm{t}^{11 / 2} \\
\left(\mathrm{~A} \cdot \mathrm{sec}^{1 / 2}\right. \\
\left.\mathrm{cm}^{-2}\right)\end{array}$ \\
\hline \multirow[t]{2}{*}{$29.05 \cdot 10^{-3}$} & $\begin{array}{l}14.4 \\
20.0 \\
24.4 \\
30.2\end{array}$ & $\begin{array}{l}0.50 \\
0.30 \\
0.20 \\
0.14\end{array}$ & $\begin{array}{l}0.216 \\
0.188 \\
0.143 \\
0.129\end{array}$ & & $\begin{array}{l}3.76 \cdot 10^{-3} \\
3.11 \cdot 10^{-3} \\
3.49 \cdot 10^{-3} \\
3.89 \cdot 10^{-3}\end{array}$ \\
\hline & & & & Avg & $3.56 \cdot 10^{-3}$ \\
\hline \multirow[t]{2}{*}{$44.3 \cdot 10^{-3}$} & $\begin{array}{l}14.4 \\
20.0 \\
30.2 \\
36.2\end{array}$ & $\begin{array}{l}0.85 \\
0.50 \\
0.20 \\
0.14\end{array}$ & $\begin{array}{l}0.290 \\
0.231 \\
0.136 \\
0.117\end{array}$ & & $\begin{array}{l}4.18 \cdot 10^{-3} \\
4.62 \cdot 10^{-3} \\
4.11 \cdot 10^{-3} \\
4.24 \cdot 10^{-3}\end{array}$ \\
\hline & & & & Avg & $4.29 \cdot 10^{-3}$ \\
\hline \multirow[t]{2}{*}{$87.9 \cdot 10^{-3}$} & $\begin{array}{l}30.2 \\
36.2 \\
40.4 \\
50.4\end{array}$ & $\begin{array}{l}0.55 \\
0.40 \\
0.30 \\
0.20\end{array}$ & $\begin{array}{l}0.245 \\
0.203 \\
0.176 \\
0.141\end{array}$ & & $\begin{array}{l}7.24 \cdot 10^{-3} \\
7.35 \cdot 10^{-3} \\
7.11 \cdot 10^{-3} \\
7.10 \cdot 10^{-3}\end{array}$ \\
\hline & & & & Avg & $7.24 \cdot 10^{-3}$ \\
\hline \multirow[t]{2}{*}{$107.0 \cdot 10^{-3}$} & $\begin{array}{l}30.2 \\
36.2 \\
40.4 \\
50.4\end{array}$ & $\begin{array}{l}0.80 \\
0.50 \\
0.40 \\
0.30\end{array}$ & $\begin{array}{l}0.295 \\
0.231 \\
0.203 \\
0.187\end{array}$ & & $\begin{array}{l}8.91 \cdot 10^{-3} \\
8.36 \cdot 10^{-3} \\
8.40 \cdot 10^{-3} \\
9.40 \cdot 10^{-3}\end{array}$ \\
\hline & & & & Avg & $8.77 \cdot 10^{-3}$ \\
\hline \multirow[t]{2}{*}{$142.7 \cdot 10^{-3}$} & $\begin{array}{l}30.2 \\
36.2 \\
40.4 \\
50.4\end{array}$ & $\begin{array}{l}1.05 \\
0.70 \\
0.60 \\
0.40\end{array}$ & $\begin{array}{l}0.338 \\
0.263 \\
0.256 \\
0.213\end{array}$ & & $\begin{array}{r}10.21 \cdot 10^{-3} \\
9.52 \cdot 10^{-3} \\
10.34 \cdot 10^{-3} \\
10.74 \cdot 10^{-3}\end{array}$ \\
\hline & & & & Avg & $10.20 \cdot 10^{-3}$ \\
\hline
\end{tabular}

Table VI. Evaluation of equilibrium constant from Table IV*

\begin{tabular}{cccc}
\hline $\begin{array}{c}\mathrm{C}_{Z_{\mathrm{nMoO}}} \\
(\mathrm{M})\end{array}$ & $\mathrm{X}$ & $\left(\mathrm{CZnMN}_{4} 0_{4}-\mathrm{X}\right)$ & $K, M-1$ \\
\hline $29.05 \cdot 10^{-3}$ & $18.38 \cdot 10^{-3}$ & $10.67 \cdot 10^{-3}$ & \\
$44.30 \cdot 10^{-3}$ & $24.88 \cdot 10^{-3}$ & $19.42 \cdot 10^{-3}$ & 31.6 \\
$87.90 \cdot 10^{-3}$ & $39.20 \cdot 10^{-3}$ & $48.70 \cdot 10^{-3}$ & 31.4 \\
$107.0 \cdot 10^{-3}$ & $44.40 \cdot 10^{-3}$ & $62.60 \cdot 10^{-3}$ & 31.7 \\
$142.7 \cdot 10^{-3}$ & $52.90 \cdot 10^{-3}$ & $89.80 \cdot 10^{-3}$ & 31.7 \\
& & & Avg 31.7 \\
& & &
\end{tabular}

* Standard deviation is \pm 0.23 .

possible to monitor the electrode potential only at $-1.65 \mathrm{~V}$ vs. Pt(II)/Pt reference electrode using current densities of $10,20,30$, and $40 \mathrm{~mA} / \mathrm{cm}^{2}$. Examination of the cathode showed only one type of solid product, a dark brown solid which adhered to the surface of the electrode. Following electrolysis, the samples were washed with distilled water and dried at $130^{\circ} \mathrm{C}$.

Qualitatively, the electrode deposit was found to contain $\mathrm{Li}, \mathrm{Zn}$, and Mo. Samples of the deposit were analyzed by the methods described. Table VII summarizes the composition of four samples of deposit prepared under identical conditions. If it is assumed that the deposit contains only $\mathrm{Li}, \mathrm{Mo}, \mathrm{Zn}$, and $\mathrm{O}$, one obtains the empirical formula $\mathrm{Li}_{2} \mathrm{Zn}_{0.5} \mathrm{MoO}_{4}$ or $\mathrm{Li}_{4} \mathrm{ZnMO}_{2} \mathrm{O}_{8}$. On the other hand it is not possible from the data given in Table VII to obtain the exact oxidation state of Mo, both because it was supposed that $\mathrm{O}=$ weight percentages add up to $100 \%$ of the sample weight and because some $\mathrm{ZnMoO}_{4}$ may be incorporated into the deposit during the electrolysis. $\mathrm{ZnMoO}_{4}$ is not soluble in water or any other suitable solvent. X-ray diffraction studies were therefore carried out on the dried sample.

Table VII. Typical andysis of $\mathrm{ZnMoO}_{4}$ deposit prepared at constant current

\begin{tabular}{|c|c|c|c|c|}
\hline & $\mathbf{A}$ & B & c & $D$ \\
\hline $\begin{array}{l}\text { Sample weight, } \mathrm{mg} \\
\text { Li, per cent weight } \\
\mathrm{Zn} \text {, per cent weight } \\
\text { Mo, per cent weight } \\
\text { Per cent weight } 0=\text { to } 100\end{array}$ & $\begin{array}{l}32 \\
6.68 \\
15.84 \\
46.65 \\
30.83\end{array}$ & $\begin{array}{c}35.3 \\
6.80 \\
15.65 \\
46.95 \\
30.60\end{array}$ & $\begin{array}{l}43.5 \\
6.75 \\
15.60 \\
47.12 \\
30.53\end{array}$ & $\begin{array}{r}61.4 \\
6.70 \\
15.79 \\
47.02 \\
30.49\end{array}$ \\
\hline
\end{tabular}
Empirical formula

(A) $\mathrm{Li}_{1.98} \mathrm{Zn}_{0.5} \mathrm{MOO}_{3.93}$

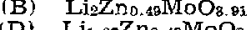


Table VIII. X-ray powder diffraction pattern of $\mathrm{ZnMoO}_{4}$ deposit prepared at constant current

\begin{tabular}{lr}
\hline $\boldsymbol{A}(\boldsymbol{A})$ & $I / I_{0}$ \\
\hline & \\
4.770 & 20 \\
4.095 & 20 \\
2.9595 & 30 \\
2.4815 & 80 \\
2.380 & 10 \\
2.0805 & 100 \\
1.8924 & 5 \\
1.8464 & 5 \\
1.6848 & 20 \\
1.5876 & 40 \\
1.4904 & 40 \\
1.4576 &
\end{tabular}

The " $d$ " spacings and relative intensities of the diffraction pattern are presented in Table VIII. The " $d$ " spacings were not comparable with any known Mo or $\mathrm{Zn}$ compound listed in the ASTM files.

From the preceding study of molybdate reduction in which the product $\mathrm{Li}_{5} \mathrm{Mo}_{2} \mathrm{O}_{3}$ was identified (4), the simplest reduction mechanism for the formation of $\mathrm{Li}_{4} \mathrm{ZnMo}_{2} \mathrm{O}_{8}$ would involve the reduction of $\mathrm{MoO}_{4}{ }^{2-}$ to $\mathrm{MoO}_{4}{ }^{3-}$, which is then incorporated into a crystal lattice with $\mathrm{Li}^{+}$and $\mathrm{Zn}^{2+}$, in the appropriate ratio. In the absence of $\mathrm{Zn}^{2+}$, both $\mathrm{MoO}_{4}{ }^{2-}$ and $\mathrm{MoO}_{4}^{3-}$ are involved in the final product.

\section{Acknowledgment}

Financial support of this research was provided by the Army Research Office, Durham, North Carolina.

Manuscript submitted April 14, 1975; revised manuscript received July 17, 1975.
Any discussion of this paper will appear in a Discussion Section to be published in the June 1976 JouRnal. All discussions for the June 1976 Discussion Section should be submitted by Feb. 1, 1976.

Publication costs of this article were partially assisted by the University of Florida.

\section{REFERENCES}

1. H. A. Laitinen and J. H. Propp, Anal. Chem., 41, 645 (1969).

2. H. A. Laitinen and K. W. Hanck, This Journal, 118, 9 (1971).

3. H. A. Laitinen and B. N. Popov, ibid., 117, 644 (1970).

4. H. A. Laitinen and B. N. Popov, ibid, 120, 1346 (1973).

5. B. N. Popov, Ph.D. Thesis, University of Zagreb (1972).

6. H. A. Laitinen and H. C. Gaur, Anal. Chim. Acta, 18, 1 (1958).

7. H. A. Laitinen and W. S. Ferguson, Anal. Chem., 38, 644 (1957).

8. A. N. Zelikman, C. A., 51, 10287i (1957), Bulletin Cdb-4 Climax Molybdenum Chemicals, Oct. (1962).

9. H. Schultze, Lieb. Ann., 126, 50 (1963), Bulletin Cdb-4 Climax Molybdenum Chemicals, Oct. (1962).

10. E. Carriere, H. Guiter, and M. Annouar, Bull. Soc. Chim. France, 261 (1948), Bull. Cdb-4 Climax Molybdenum Chemicals, Oct. (1962).

11. W. Jander, Z. Anorg. Allgem. Chem., 190, 399 (1930), Bull. Cdb-4 Climax Molybdenum Chemicals, Oct. (1962).

12. G. H. Aylward, Anal. Chim. Acta, 14, 386 (1956).

\title{
Kinetics of Electrogenerative Hydrogenation over Platinum Black Electrocatalyst
}

\author{
Stanley H. Langer* and George P. Sakellaropoulos* \\ Department of Chemical Engineering, University of Wisconsin, Madison, Wisconsin 53706
}

\begin{abstract}
The kinetics of the electrocatalytic hydrogenation of ethylene at positive potentials has been studied over polytetrafluoroethylene-bonded, porous platinum black electrodes in perchloric acid electrolyte. Pore diffusion was generally not a significant factor except at low concentrations of reactants. Steadystate kinetic parameters and deuterium exchange results suggest that surface reaction of hydrogen with ethyl radicals is rate limiting. A mechanistic model is proposed and examined in terms of Temkin adsorption of hydrogen atoms in the low potential region $(<0.18 \mathrm{~V})$. Strong Langmuir adsorption of ethylene appears to take place for all mechanisms considered. The energy production of the electrogenerative reactor is favored by high electrolyte concentration, high alkene partial pressure, elevated temperatures, and increased catalytic loading.
\end{abstract}

Few electrocatalytic reactions have been well characterized; the frequent referral to hydrogen and oxygen electrode reactions, and not many others, in the context of "electrocatalysis" is symptomatic of this situation. The electrocatalytic nature of electrogenerative hydrogenation and the availability of significant amounts of information.on the process from earlier investigations (1-6) stimulated a study of the kinetics of the hydrogenation reaction at an ethylene electrode

- Electrochemical Society Active Member.

Key words: ethylene, catalysis, porous electrodes, deuterium exchange. with porous platinum black electrocatalyst. Such kinetic information should provide an additional basis for comparison with conventional catalytic hydrogenation $(7-10)$ and with other reactions, which utilize these and similar electrodes for generation of current.

This electrogenerative process involves the operation of a hydrogen electrode against a hydrogenating olefinic electrode separated by an aqueous, acidic, barrier electrolyte phase (1-3). The external circuit between the electrodes is regulated to allow operation at varying voltages and currents generated by the reacting species. The olefinic electrode operates at positive po- 